Climate of the Past Discussions

\title{
Correcting mean and extremes in monthly precipitation from 8 regional climate models over Europe
}

\section{B. Kurnik, L. Kajfež-Bogataj, and A. Ceglar \\ University of Ljubljana, Biotechnical faculty, Ljubljana, Slovenia}

Received: 4 February 2012 - Accepted: 9 March 2012 - Published: 26 March 2012

Correspondence to: B. Kurnik (blaz.kurnik@eea.europa.eu)

Published by Copernicus Publications on behalf of the European Geosciences Union.

Correcting mean and extremes in monthly precipitation

B. Kurnik et. al

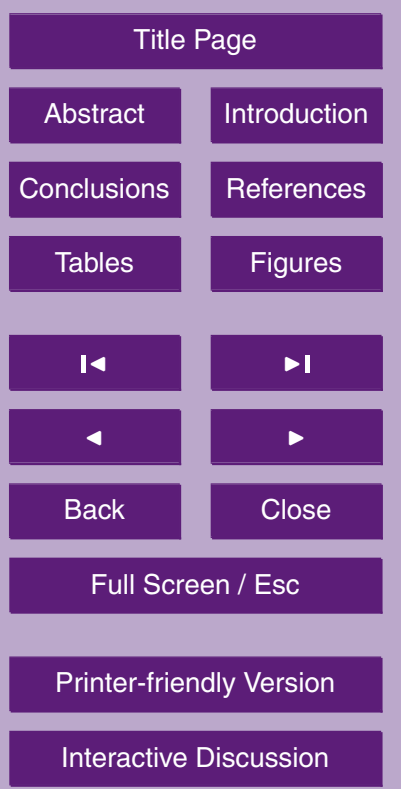




\section{Abstract}

We corrected monthly precipitation from 8 regional climate models using statistical bias correction. All models were corrected according to observations and parameters for bias correction were obtained for all models separately in every grid cells over Euro5 pean domain, using data between 1961 and 1990. Bias correction was validated in the period between 1991 and 2010 with RMSE, Brier score and Brier skill score. The results are encouraging, as mean and extremes were effectively corrected. After applying correction, large biases over Alps, at the East Adriatic cost, west coast of Norway and at the east end of the domain were removed. RMSE of corrected precipitation was lower than RMSE of simulated in $85 \%$ of European area and correction for all models failed in only $1.5 \%$ of European area. Also extremes were effectively corrected. According to the Brier skill score the probability for dry months was corrected in more than $52 \%$ of the European area and heavy precipitation events were corrected in almost $90 \%$ of the area. All validation measures suggest the correction of monthly precipitation was suc15 cessful and therefore we can argue that the corrected precipitation fields will improve results of the climate impact models.

\section{Introduction}

Europe is experiencing an increasing number of disasters due to the natural hazards. According to the EEA technical report (EEA, 2011) we experienced more than 500 major natural hazard events between 1998 and 2009, which caused more than 100 billion Euros of overall loses. Almost half of these events were directly connected with the extremes in precipitations (floods and droughts). Moreover, there is some evidence that climate change is contributing to increasing of the frequency and intensity of water natural hazards (Wang, 2005; Burke et al., 2006; Solomon et al., 2007; Burke and 25 Brown, 2007). Hence, accurate evaluation of climate hazards is extremely important for risk and vulnerability studies.
8, 953-986, 2012

\section{Correcting mean and extremes in monthly precipitation \\ B. Kurnik et. al}
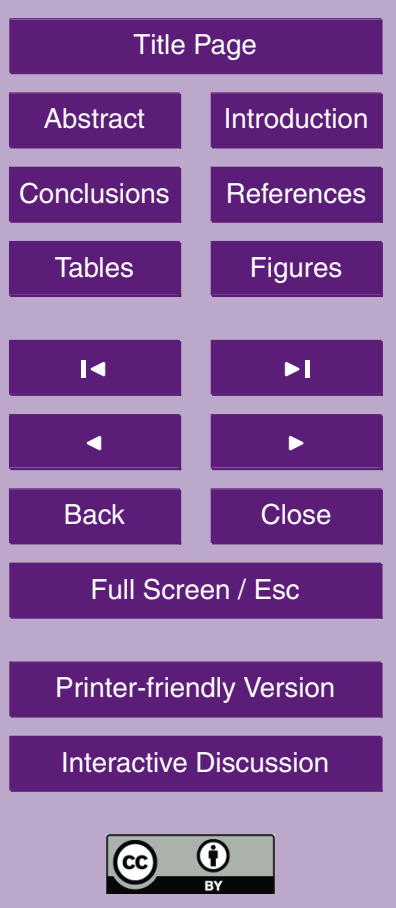
Direct outputs from global and regional climate models (RCM) in the future climate are presented in terms of relative changes. Baseline statistic is defined according to model hindcasts and it always differs from observations. It is well known the results of RCMs cannot be directly used as an input for impact models without prior corrections 5 of their outputs. RCM's representation of climate variables is not realistic and direct use of the data in the impact models can produce unrealistic results (Piani et al., 2010b,a; Semenov and Doblas-Reyes, 2007). Simulated precipitation is generally affected by a positive bias in the number of wet days, which is partly compensated by an excessive number of drizzles (Piani et al., 2010b). On the other hand models cannot accurately 10 reproduce extreme precipitation events (Biagorria et al., 2007; Lander and Buishand, 2007).

Impact modelers use statistical methods for correcting climate model results. Various authors (Sharma et al., 2007; Hansen et al., 2006) described several statistical methods for correcting climate models outputs and called them statistical bias correc15 tion. In two recent studies, Piani et al. (2010b) and Piani et al. (2010a) suggested and described several methods for bias correction of precipitation and temperature fields. These methods not only correct mean values, but they affect all statistical moments of climatological variables. Suggested methods usually involve a procedure in which a transfer function is derived from cumulative distribution function of simulated and observed variable. The methodology is described in details by Piani et al. (2010a), where they were correcting daily precipitation outputs from Danish meteorological institute (DMI) RCM (Christensen et al., 2002).

In the recent years outputs from several Regional Climate models (RCMs) were made available. In the frame of the European project ENSEMBLES (van der Linden and Mitchell, 2009) outputs from several (up to 25) RCMs were produced with the main objective to use data in climate impacts studies.

In this study we have used monthly precipitation fields over Europe from $8 \mathrm{RCMs}$ and have corrected them against observation from E-OBS data set (Haylock et al., 2008). In order to obtain valid bias correction we have used several assumption. (i) Bias behavior
8, 953-986, 2012

\section{Correcting mean and extremes in monthly precipitation \\ B. Kurnik et. al}
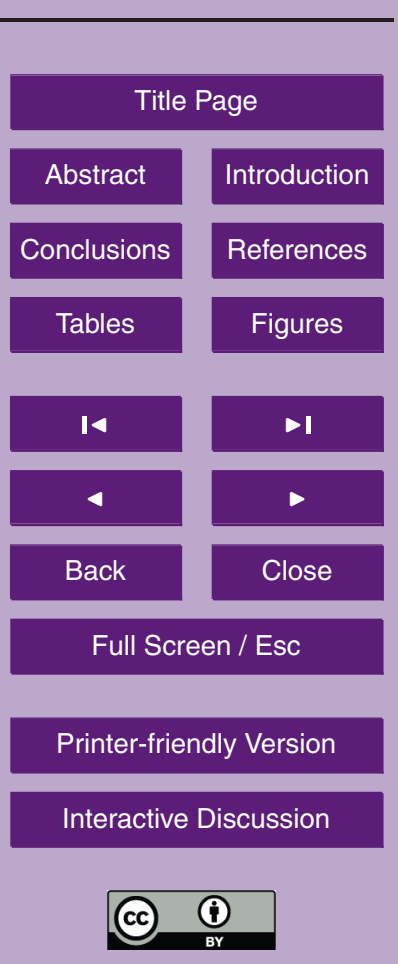
of models is timely independent, therefore we assume it remains valid also in the future climate conditions. (ii) Bias correction is limited with the quality of observed data, thus, accurate observed precipitation fields are essential for both correction of the models and validation of the results.

5 The main focus of this paper is to prepare the most accurate input data in order to assess climate impact on meteorological droughts in current and changed climate conditions. As drought is creeping phenomena, which can easily be detected with monthly time step (Burke and Brown, 2007), we have focused on correcting precipitation fields in monthly time-step. The studies of risk and vulnerability to droughts are thus more 10 accurate.

All results are presented either for the whole ensemble or for each ensemble member separately. We focused on the correction of dry events, however we present also effects of corrections on mean yearly and July precipitation, correction of the ensemble spread and effects on heavy precipitations. In addition, we used various validation tools and

\section{Data and methodology}

\subsection{Bias correction}

Monthly precipitation from RCMs was corrected according to the observations. Method for correcting the precipitation is based on adjusting the cumulative distribution function (CDF) of raw RCM simulations to CDF of observations at every grid cell separately. Similar approach for correcting modeled precipitation was already used by (Sennikovs and Bethers, 2009; Piani et al., 2010a) and others. Method is based on the assumption that both, observed and modeled precipitation, follow theoretical probability distribution function from same distribution family (e.g. gama distribution function). The correction of precipitation consists of several steps. In first step, probability density function is fitted to precipitation data from RCM simulations and observations. Many researchers,

8, 953-986, 2012

Correcting mean and extremes in monthly precipitation

B. Kurnik et. al

\section{Title Page}

Abstract Introduction

Conclusions

Tables References

Figures

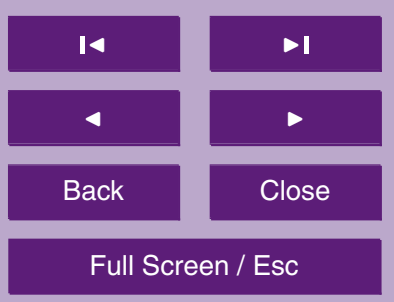

Printer-friendly Version

Interactive Discussion

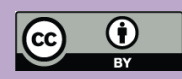


like Thom (1958), Wilks (1990), Ben-Gai et al. (1998) and Piani et al. (2010a) have discussed about distribution function of various meteorological variables and it was concluded that precipitation generally follows gamma distribution, which is described with Eq. (1):

${ }_{5} \operatorname{pdf}(x, \alpha, \beta)=\frac{e^{-\frac{x}{\beta}} x^{\alpha-1}}{\Gamma(\alpha) \beta^{\alpha}}$.

After integrating probability density function (Eq. 1), we get the cumulative density function:

$\operatorname{cdf}(x, \alpha, \beta)=\int_{0}^{x} \frac{e^{-\frac{x^{\prime}}{\beta}} x^{\prime \alpha-1}}{\Gamma(\alpha) \beta^{\alpha}} d x^{\prime}$

where $x$ is normalized monthly precipitation, $\alpha$ is form and $\beta$ scale parameter, respectively. Both, $\alpha$ and $\beta$, have to be greater than zero. The fitting of the distribution was done using "moment matching estimation" (MME). The method of moment matching can be applicable also for the periods with no precipitation, which becomes important in dry regions of Europe. According to Thom (Thom, 1958), this method is not efficient for relatively small values of the form parameters.

15 In second step, we developed the transfer function $y=f(x)$, where $x$ and $y$ are simulated and corrected values of monthly precipitation, respectively. Because we are adjusting the distribution of simulated precipitation to the distribution of observed precipitation, the corrected precipitation needs to follow the distribution of observed precipitation as shown in following equation: $\operatorname{cdf}_{\mathrm{obs}}(y)=\mathrm{cdf}_{\mathrm{sim}}(x)$. Therefore, the equation

$y=f(x)=\operatorname{cdf}_{\text {obs }}{ }^{-1}\left[\mathrm{cdf}_{\text {sim }}(x)\right]$

Since the gamma distribution is undefined for $x=0$ and since we observed significant number of grid cells, where probability of $x=0$ is higher than zero, we need to introduce additional parameter into transfer function - probability of zero precipitation.

Correcting mean and extremes in monthly precipitation

B. Kurnik et. al Title Page

Abstract

Introduction

Conclusions

Tables

References

Figures

14

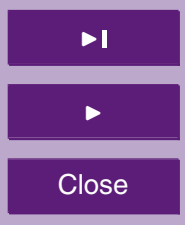

Back

Close

Full Screen / Esc

Printer-friendly Version

Interactive Discussion

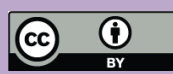




\subsection{Observed and modeled datasets}

Validation of the methodology was done using simulated and observed monthly precipitations from observation data set and from 8 different RCMs. Data between 1961 and 1990 were used for the calibration of transfer function, whereas data between 1991 5 and 2010 were used for validation.

All data, used for this paper, were produced by partners in ENSEMBLES project (van der Linden and Mitchell, 2009). The ENSEMBLES project developed an ensemble prediction system on the seasonal to centennial time-scales. In addition, project quantified the uncertainty in climate modeling and linked prediction system with range their $\mathrm{RCM}$ at $25 \mathrm{~km}$ spatial resolution with boundary condition from five GCMs, all usthe $25 \mathrm{~km}$ spatial resolution with boundary condition from five GCMs, all using SRES A1B scenario (Nakicenovich and Swart, 2000). At the end, 25 runs of the models were produced. For this study only those models were selected, which cover extended European domain and time period between 1951 and 2099. In addition, we have excluded simulations, driven by the global models HadCM3Q3 and HadCM3Q16, in which historical climate is not well simulated (Christensen, personal communication). Following the criteria, we specified earlier, 8 different model runs (as combination of 6 different RCMs, driven by 4 different GCMs) were selected:

- Rossby Centre (Swedish meteorological and hydrological institute) regional atmospheric climate model (RCA3) (Kjellstrom et al., 2005) using Bergen climate global model (RCM) for boundary condition (Furevik et al., 2003)(hereafter called as SM1).

- Rossby Centre (Swedish meteorological and hydrological institute) regional atmospheric climate model (RCA3) (Kjellstrom et al., 2005) using Max Planck institute's ECHAM version 5 (Roeckner et al., 2003) global model for boundary condition (hereafter called as SM2).

8, 953-986, 2012

Correcting mean and extremes in monthly precipitation

B. Kurnik et. al

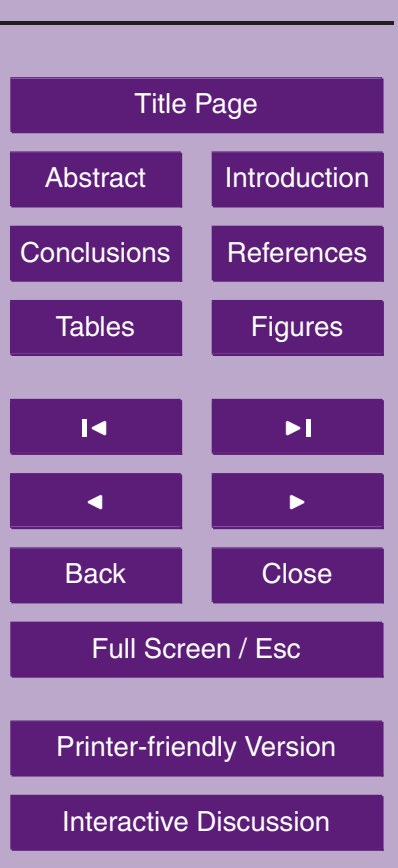


- Regional Climate model - REMO (Jacob, 2001) from Max-Planck institute for meteorology using ECHAM version 5 (Roeckner et al., 2003) global model from same institute for boundary condition (hereafter called as MPI).

- Regional Climate Atmospheric Model from KNMI (Dutch Meteorological Institute) - RACMO version 2 (Lenderink et al., 2003) using ECHAM version 5 (Roeckner et al., 2003) global model from same institute for boundary condition (hereafter called as KNM).

- CLM - Climate Version of "Local Model" (Bohm et al., 2006) developed at the Technical University in Zuerich (UTHZ) driven with boundary conditions from UK Met office - Hadley Centre coupled model HadCM3Q0 (Gordon et al., 2000) (hereafter called as ETH).

- HIRHAM version 5 (Christensen et al., 2007) developed and used at the Danish meteorological institute with boundary conditions from ECHAM version 5 global model (Roeckner et al., 2003) (hereafter called as DM1).

- HIRHAM version 5 (Christensen et al., 2007) developed and used at the Danish meteorological institute using boundary condition from ARPEGE version 5 climate model(Meteorologiques, 2008), developed at the Climate Research unit of Meteo France (hereafter called as DM2).

- Climate version of the ALADIN regional model (Somot, 2006) from Climate Research unit of Meteo France, with boundary conditions from ARPEGE version 5 climate model (Meteorologiques, 2008), developed at the Climate Research unit of Meteo France (hereafter called as CNR).

Table 1 represents precipitation anomalies of each ensemble member in terms of intra-ensemble standard deviation for winter and summer precipitation. Smallest from ensemble mean in winter and summer, respectively. On the other hand, DM2 959
8, 953-986, 2012

Correcting mean and extremes in monthly precipitation

B. Kurnik et. al
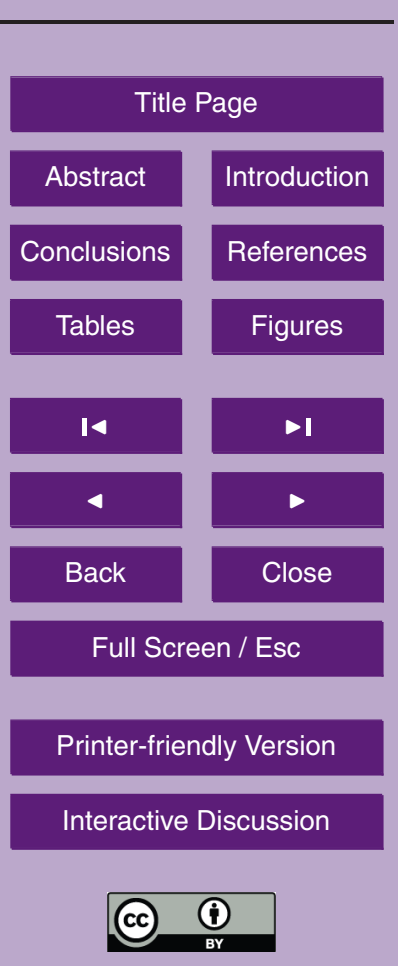
deviates the most from the mean in winter and summer. The ranking should not be interpreted as a quality mark. There is an obvious bias from the fact that ECHAM5 is dominating as a driving GCM and there is no reason to believe that this global simulation has a higher quality than the others. This ranking was made only to show general 5 differences between models in order to have a general background.

Dataset of observed gridded precipitation (E-OBS) has also been produced in the frame of the ENSEMBLES project. This data set has been designed to provide the best estimate of grid box averages, rather than point values, to enable direct comparison with RCMs. The observed data set was defined on the same 0.25 degree grid 10 resolution. Precipitation from original daily resolution, existing between 1950 and 2010, was aggregated into monthly time resolution. Only data between 1961 and 2010 were used for purpose of this study.

The transfer function $y=f(x)$ was defined using monthly precipitation between 1961 and 1990 for all grid cells and all RCMs. Gama distribution was fitted to monthly precipitation, resulting in estimations of parameters $\alpha$ and $\beta$ for each grid cell. Probability for dry grid cell (Fig. 1) has been used as an additional parameter in transfer function. Hence, 27 parameters were defined for every grid point ( 3 parameters for each RCM and 3 parameters for observations).

\subsection{Validation}

20 Comparison of raw and corrected RCM simulations with observed precipitation data from 1991 until 2010 was used to validate the methodology. Ensemble median was calculated as a 50th percentile of precipitation from 8 ensemble members, whereas ensemble spread was defined as a difference between 75 th and 25th percentiles. Root mean square error (RMSE) was used for the quantification of the differences between
8, 953-986, 2012

Correcting mean and extremes in monthly precipitation

B. Kurnik et. al

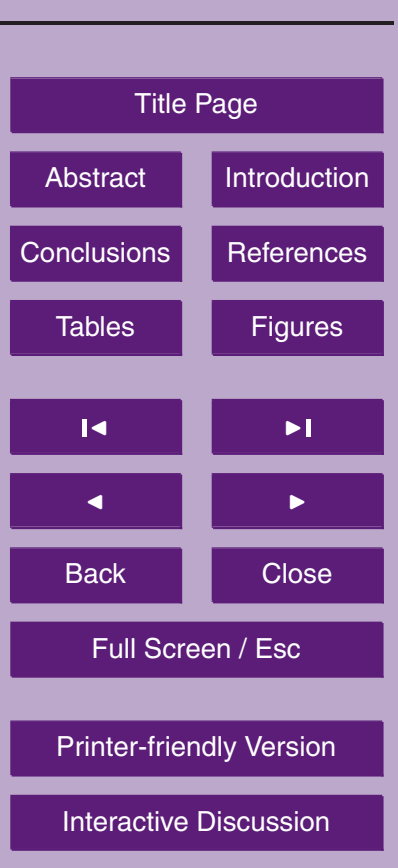

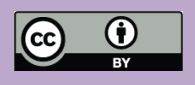


culated as Eq. (4):

$\operatorname{RMSE}=\frac{1}{n} \sqrt{\sum_{j=1}^{n}\left(m_{j}-o_{j}\right)^{2}}$

8, 953-986, 2012

where $n$ is the number of grid cells in study area, $m_{j}$ is modeled value and $o_{j}$ is observed value.

5 Validation of the extremes was performed with simple scalar accuracy measures, like Brier score (BS) and Brier skill score (BSS). Brier score (Brier, 1950) is primarily used for verification of probabilistic binary meteorological forecasts or climatological predictions. It is a quadratic scoring measure for the quantitative evaluation (Eq. 5):

$\mathrm{BS}=\frac{1}{n} \sqrt{\sum_{j=1}^{n}\left(p_{j}-x_{j}\right)^{2}}$

10 where $n$ is the number of grid cells of the study area, $p_{j}$ is the forecast probability of the occurrence of the binary event and $x_{j}$ is a value equal to 1 or 0 (event occurred or not). The best probabilistic prediction has a Brier score 0 , whereas the worst has value 1.

BSS was used to evaluate the skill of the corrected precipitation. We compare corrected $B S$ and simulated $B S$ from all ensemble members, as described in Eq. (6):

$\mathrm{BSS}=1-\frac{\mathrm{BS}_{\mathrm{cor}}}{\mathrm{BS}_{\text {sim }}}$

The BSS is equal to 1 for a perfect correction of the precipitation fields and 0 or negative for a corrections which perform worse than raw RCM simulations.

Correcting mean and extremes in monthly precipitation

B. Kurnik et. al

Title Page

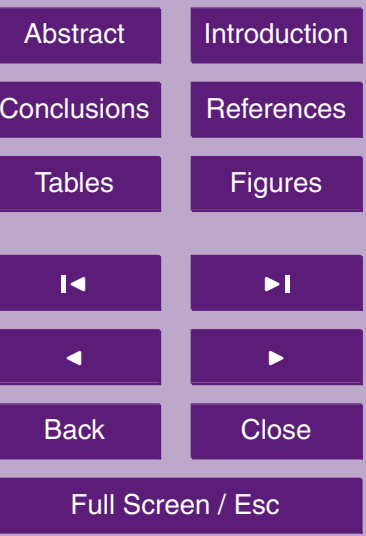

Printer-friendly Version

Interactive Discussion 


\section{Results}

\subsection{Evaluation of corrections for average precipitation}

\subsubsection{Yearly and monthly averages}

Methodology was validated using data from the period 1991-2010. Data, used for cal5 culating transfer functions and data, used for validation, came from 2 different periods without any overlaps of time-series. Monthly precipitation from 8 different models have been corrected and results have been presented by the means of maps and graphs or as a statistical moments of the ensembles.

Maps of ensemble median, 25th and 75th percentiles of corrected (ECOR) and simulated (ESIM) average yearly precipitation are presented. Ensemble median of the ECOR (Fig. 3b) is closer to the observed values than ESIM (Fig. 3a). Moreover, the values of 25th and 75th percentiles of the ECOR (Fig. 4b) are less spread than ones of ESIM (Fig. 4a). These results were expected; according to definition of correction method, moments of statistical distribution have to be similar to the observed ones 15 (Fig. 2). We applied the same transfer function for July to test, how it works for average summer precipitation. The results on Fig. 5a, b and Fig. 6a, b are encouraging, as the correction is effective also for specific month.

\subsubsection{RMSE of monthly precipitation}

RMSE was used for the quantification of the differences between observed and simulated or corrected monthly precipitation values. RMSE was calculated for validation period in every grid cell, covering European domain. As expected, RMSE of corrected precipitation (Fig. 7b) has been generally lower than RMSE of simulated precipitation (Fig. 7a). Moreover, the results showed that RMSE of corrected precipitation for the whole ensemble was up to 50 percent lower than RMSE of simulated precipitation.

Large biases of simulated precipitation over Alps, at the East Adriatic coast, west coast
8, 953-986, 2012

Correcting mean and extremes in monthly precipitation

B. Kurnik et. al

\section{Title Page}

Abstract

Introduction

Conclusions

References

Tables

Figures

14

DI

4

Back

D

Close

Full Screen / Esc

Printer-friendly Version

Interactive Discussion

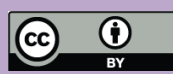


of Norway and at the east of the domain were also removed after applying corrections. This results are encouraging, however with RMSE we only validated average differences in precipitation for all members of the ensemble.

In order to assess the performance of single ensemble member using the whole 5 precipitation spectrum, we compared their RMSEs. The results are presented in the percentages of Europe where the RMSE of the corrected precipitation (RMSE $\left.{ }_{c o r}\right)$ was higher than RMSE of simulated precipitation $\left(\mathrm{RMSE}_{\text {sim }}\right.$ ) (in the other words, percentage of Europe where correction was not effective) (Fig. 8). Model with the largest European area, where correction failed, is ETH, with more than $\frac{1}{4}$ of the European land area. 10 More than $20 \%$ of failure can also be observed for the MPI model. Corrections for KNM, CNR, DM2, SM1 and SM2 failed between 10 and $15 \%$ of European area. The most effective correction was observed for DM1, where more the $90 \%$ of the area was sucessfully corrected. Considering all ensemble members, $16 \%$ of the area was not successfully corrected. Only in $1.5 \%$ of the area correction failed in all cases (in $4.5 \%$ cases correction failed for at least 6 models).

Spatial distribution of the fails is presented in Fig. 9. This figure shows number of the ensemble members when the RMSE ${ }_{\text {cor }}$ was higher then $\mathrm{RMSE}_{\text {sim. }}$. Number varies between 0 and 8 , with 0 representing cases, where none of the models had RMSE higher than $\mathrm{RMSE}_{\text {sim. }}$. Oppositely, number 8 represents cases, where the correction failed for all models. 6 or more models failed (dark green in the figures) in the west coast of Norway, north-west coasts of British isles and in the Central and Eastern Europe. Poor correction can also be observed over the Turkey, East Spanish coast and North Italy. Corrections were effective in large part of the domain, namely France, Northern Germany, Poland and East Scandinavia. In east border of the domain large overestimations were removed, resulting in lower $\mathrm{RMSE}_{\text {cor }}$ than $\mathrm{RMSE}_{\text {sim }}$ for all models.
8, 953-986, 2012

\section{Correcting mean and extremes in monthly precipitation \\ B. Kurnik et. al}

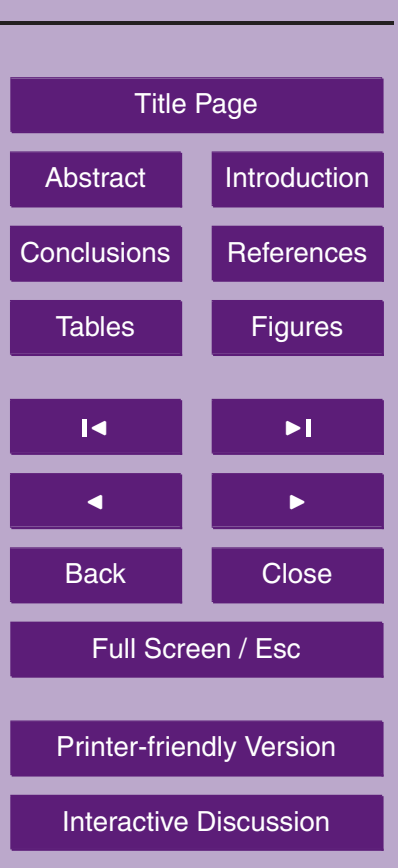




\subsection{Evaluating correction of the extremes}

\subsubsection{Area under extreme precipitation}

We explored the method further and tested methodology performance on the precipitation extremes. Both tails of the distribution, zero precipitation on one hand and heavy or 5 extreme precipitation on other hand, were validated. Also here we compared corrected and simulated precipitation from all ensemble members with observations, using differences in area (in \%) as a performance indicator.

First we present the performance of the correction for dry months. Due to the fact the originally models produce precipitation in each time step, threshold of $10 \mathrm{~mm}$ for dry months was defined. With this threshold we removed unrealistic drizzles produced by RCMs. Figure 10 summarizes average differences in area between modeled (corrected and simulated) and observed dry month for all 8 models, respectively. High performance can be observed for the correction methodology, since the differences between modeled and observed area under threshold drop significantly after applying corrections. The average difference between observed and corrected precipitation, using all ensemble members, is less than $1 \%$ (varies between $-2 \%$ and $2 \%$ ) while difference between simulated and observed is almost $6 \%$ (varies between 3 and $10 \%$ ). According to Fig. 10, raw simulated precipitation overestimates area in all cases, while corrected precipitation overestimates area in 4 cases (DM1, DM2, KNM, and ETH) and underestimates area with zero precipitation in SM1, SM2, MPI, and CNR models.

Similarly as for dry events, we evaluate performance of correction also in the case of heavy precipitation. Figures 11 and 12 show differences between observations and simulated precipitation in 8 ensemble members (before and after correction, expressed in percentages of area) for two thresholds: precipitation higher than $200 \mathrm{~mm}$ and pre25 cipitation higher than $400 \mathrm{~mm}$, respectively. In these two cases bias correction was also effective, because differences were smaller after applying corrections for all ensemble members. Even more, correction for precipitation above $200 \mathrm{~mm}$ was highly effective, leading to no significant differences in areas after corrections. In two cases
8, 953-986, 2012

\section{Correcting mean and extremes in monthly precipitation \\ B. Kurnik et. al}

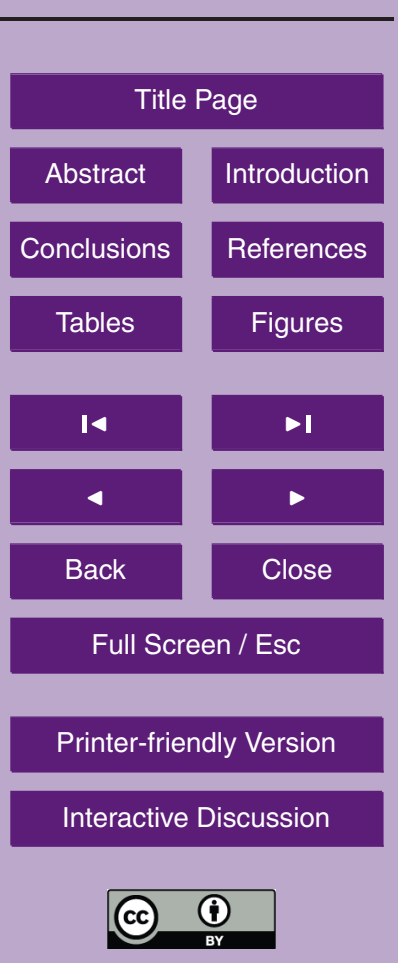


(models DM1 and SM1) the correction decreased the differences from $8 \%$ (DM1) and $6 \%$ (SM1) to around 0,1\%. Similar results we get also for $400 \mathrm{~mm}$ threshold.

\subsubsection{Performance of correction on extreme precipitation}

We used BS and BSS to validate the performance of corrections on the extremes 5 of distribution, taking into account the whole ensemble. Two thresholds were taken (thresholds of zero precipitation and $200 \mathrm{~mm}$ ) and BS for corrected $\left(\mathrm{BS}_{\text {cor }}\right)$ and simulated $\left(\mathrm{BS}_{\text {sim }}\right)$ precipitation were calculated. We noticed that BS for corrected (Fig. 14b) and simulated (Fig. 14a) precipitation are very similar for both thresholds, leading to difficult identification of differences only by looking at figures. We have therefore apo plied BSS to identify the skill of corrections. According to BSS, corrections for both, zero and heavy precipitation, were effective. BSS for dry events is positive (we have skillful corrections) in around $53 \%$ of analyzed area. In case of heavy precipitations almost $90 \%$ of the European area was effectively corrected (Fig. 15). The validation in the case of dry events is positive, though arguably not as good as in the case of 15 heavy precipitation. Regions with high probability of dry month (Spain, Mediterranean, Central and Southeastern Europe) however show positive BSS with values even close to 1 (perfect match between models and observations). The improvements are less good in Central and east part of domain (isolated area with large negative BSS) in the majority of the Scandinavia and British isles. These negative corrections of zero pre20 cipitation occurred in the areas where we observed low probability for dry month and where agreement between simulated and corrected precipitation fields was high (close values for $\mathrm{BS}_{\mathrm{cor}}$ and $\left.\mathrm{BS}_{\mathrm{sim}}\right)$.

Share of the European area where we have positive skill in correcting heavy precipitation is higher than in the case of dry events. Large part of the domain has BSS 25 close to 1 and only in less than $10 \%$ of the area correction was not effective. These negative corrections were observed in the area where precipitation (observed and simulated) were close to the threshold. For $400 \mathrm{~mm}$ threshold (not shown here) the BSS was positive in almost $98 \%$ of the cases.
8, 953-986, 2012

Correcting mean and extremes in monthly precipitation

B. Kurnik et. al
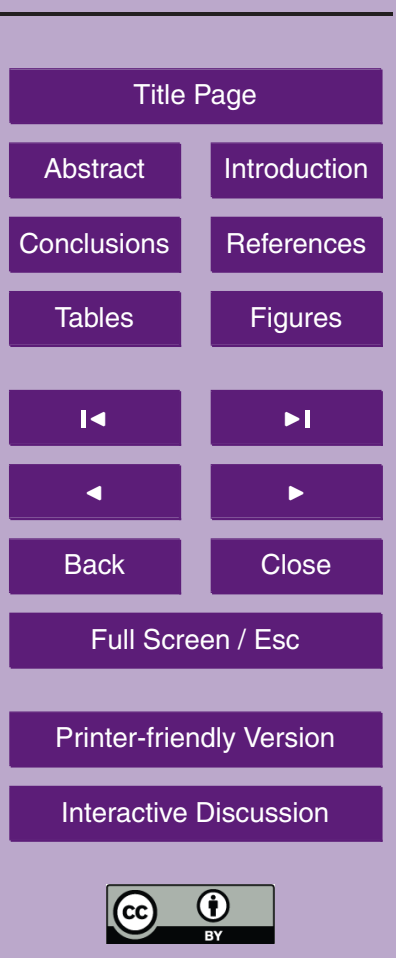


\section{Discussion and conclusions}

We corrected monthly precipitation fields from 8 RCMs from the ENSEMBLES project. Statistical bias correction method was used to overcome the difference between simulated and observed precipitation. Transfer function was obtained using data from the 5 period (1961-1990) without any distinguish between months or seasons. Validation of the results was done using the period between 1991-2010. We applied individual transfer functions to every ensemble member, respectively. Validation focused on the performance of the whole ensemble and in some cases (such as area under defined precipitation thresholds) we evaluated performances of single ensemble member.

Yearly precipitation from all ensemble members were effectively corrected. The ensemble spread was much lower after applying the correction, which was expected as all models were corrected according to the same observation dataset. We got similar results in the case of July precipitation. Average precipitation from all ensemble members were effectively corrected, leading to much lower ensemble spread. This clearly shows that corrections were effective also in case of July precipitation even when the transfer function was obtained without distinction in seasons or months.

Great improvements in precipitation fields after corrections could be observed according to RMSE. RMSE of the corrected precipitation was always lower than $16 \mathrm{~mm}$, while RMSE of simulated precipitation was 2 times higher (up to $30 \mathrm{~mm}$ ). Large biases over the Alps and East Adriatic coast werecompletely removed, whereas biases over West Norwegian coast, West Iberian Peninsula and East Scotland decreased significantly. Moreover, in more than $80 \%$ of the area, corrected precipitation from all models had lower RMSE than simulated. Corrections for all models were not effective for only $2 \%$ of the area.

25 In the last step we validated the correction of dry months (zero precipitation) and extremely high monthly precipitation. Corrections were effective also for extremes. Differences between observed and modeled area below (above in the case of heavy precipitation) thresholds almost disappeared after correcting the RCM simulations. Reflecting
8, 953-986, 2012

\section{Correcting mean and extremes in monthly precipitation \\ B. Kurnik et. al}
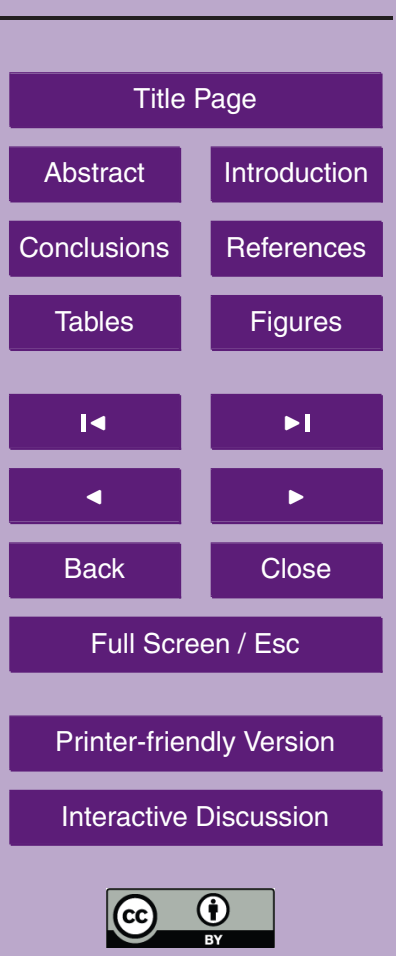
to the BSS as validation measure, corrections were effective in more than $52 \%$ of the area in the case of dry extremes and more than $80 \%$ in the case of heavy precipitation.

All validation measures suggest that correction of monthly precipitation was successful. Mean yearly and monthly precipitation was corrected in all cases. Ensemble spread 5 was lower after applying corrections and differences between observed and modeled areas below or above thresholds disappeared. Lower performance of the corrections was detected when comparing models and observation in the same time step (using RMSE and BS or BSS). However the aim of the climate impacts modeling is not being accurate in the specific time step, but to improve the model output statistics in order to 10 be close to reality as much as possible. We can conclude the corrected data set can be use for assessing climate impact on droughts in current or changed climate conditions.

Acknowledgements. Data were obtained from ENSEMBLES project (contract GOCE-CT 2003505593) via DMI data portal with help from O. B. Christensen.

\section{References}

15 Centre National De Recherches Meteorologiques, Arpege - climate version 5.1., Technical report, Meteo France - Centre National De Recherches Meteorologiques, September 2008, available online at: http://www.cnrm.meteo.fr/gmapdoc/IMG/pdf_arp51ca.pdf, 2008. 959

Ben-Gai, T., Bitan, A., Manes, A., Alpert, P., and Rubin, S.: Spatial and temporal changes in rainfall frequency distribution patterns in israel, Theor. Appl. Climatol., 61, 177-190, 1998. $20 \quad 957$

Biagorria, G. A., Jones, J. W., Shin, D. W., Mishra, A., and O'Brien, J. J.: Assessing uncertainties in crop model simulations using daily bias-corrected regional circulation model outputs, Climate Res., 3, 211-222, 2007. 955

Bohm, U., Kucken, M., Ahrens, W., Block, A., Hauffe, D., Keuler, K., Rockel, B., and Will, A.: $25 \quad \mathrm{Clm}$ - the climate version of Im: Brief description and long-term applications. Technical report, Postdam Institute for Climate Impact Research, Germany, http://www.clm-community. eu/dokumente/upload/3a8e8_COSMOnewsLetter06_clm.pdf, 2006. 959
8, 953-986, 2012

\section{Correcting mean and extremes in monthly precipitation}

B. Kurnik et. al

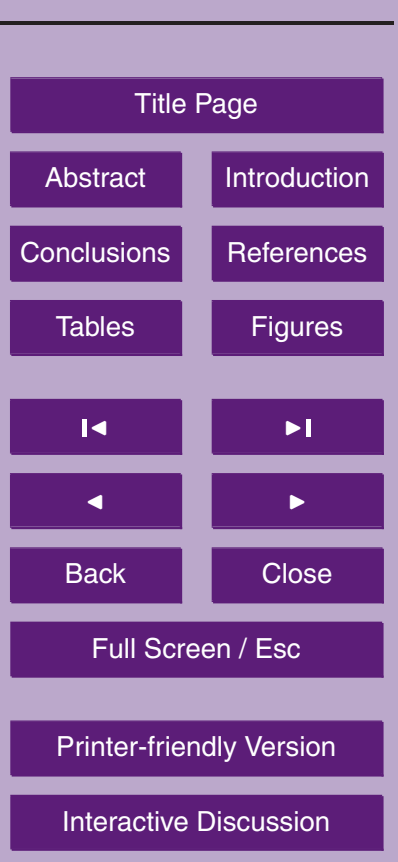


Brier, G. W.: Verification of forecasts expressed in terms of probability, Mon. Weather Rev., 78, 1-3, 1950. 961

Burke, E. J. and Brown, S. J.: Evaluating uncertainties in the projection of future drought, J. Hydrometeorol., 9, 292-299, 2007. 954, 956

5 Burke, E. J., Brown, S. J., and Christidis, N.: Modeling the recent evolution of global drought and projections for the 21 st century with the hadley centre climate model, J. Hydrometeorol., 7, 1113-1125, 2006. 954

Christensen, J. H., Carter, T. R., Rummukainen, M., and Amanatidis, G.: Prudence employs new methods to assess european climate change, EOS Transactions AGU, 82, 2007. 955

Christensen, J. H., Christensen, O. B., Lopez, P., Meijgaard, E., and Botzen, M.: The hirham4 regional atmospheric climate model, DMI Scientific Report, Technical report 06-17, Danish Meteorological Institute, available online at: www.dmi.dk/dmi/tr, 2007. 959

Furevik, T., Bentsen, M., Drange, H., Kindem, I. K. T., Kvamsto, N. G., and Sorteberg, A.: Description and evaluation of the bergen climate model: arpege coupled with micom, Clim.

15 Dynam., 21, 27-51, 2003. 958

Gordon, C., Cooper, C., Senior, C. A., Banks, H., Gregory, J. M., Johns, T. C., Mitchell, J. F. B., and Wood, R. A.: The simulation of sst, sea ice extents and ocean heat transports in a version of the hadley centre coupled model without flux adjustment, Clim. Dynam., 16, 147-168, 2000. 959

20 Hansen, J. W., Challinor, A., Ines, A., Wheeler, T., and Moronet, V.: Translating forecasts into agricultural terms: advances and challenges, Climate Res., 33, 27-41, 2006. 955

Haylock, M. R., Hofstra, N., Klein-Tank, A. M. G., Klok, E. J., Jones, P. D., and New, M.: A european daily high-resolution gridded dataset of surface temperature and precipitation, J. Geophys. Res., 113, D20119, doi:doi:10.1029/2008JD10201, 2008. 955

Jacob, D.: A note to the simulation of the annual and inter-annual variability of the water budget over the baltic sea drainage basin, Meteorol. Atmos. Phys., 77(1-4), 61-73, 2001. 959

Kjellstrom, E., Barring, L., Gollvik, S., Hansson, U., Jones, C., Samuelsson, P., Rummukainen, M., Ullerstig, A., Willen, U., and Wyser, K.: A 140-year simulation of european climate with the new version of the rossby centre regional atmospheric, Technical report,

$30 \quad$ Swedish meteorological and hydrological insitute, 2005. 958

Lander, R. and Buishand, T. A.: Re-sampling of regional climate models output for the simulation of the extreme river floods, J. Hydrol., 3(332), 487-496, 2007. 955
8, 953-986, 2012

\section{Correcting mean and extremes in monthly precipitation}

B. Kurnik et. al

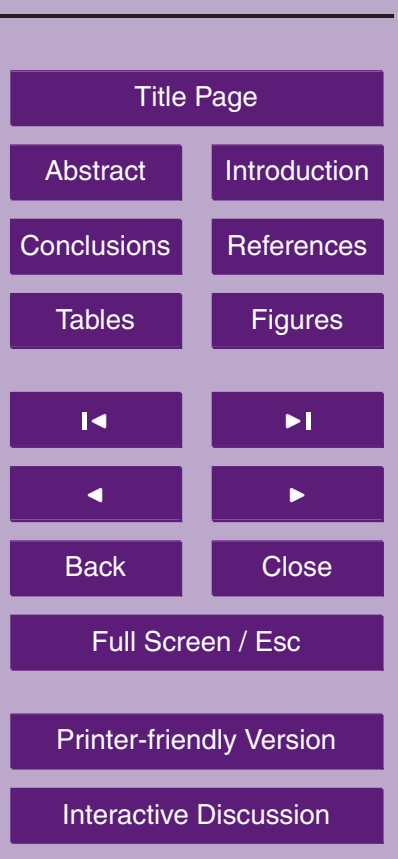


Lenderink, G., van den Hurk, B., van Meijgaard, E., van Ulden, A., and Cuijpers, J.: Simulation of present-day climate in racmo2: first results and model developments, Technical report, report 252, Koninklijk Nederlands Meteorolohisch Instituut, De Bilt (The Netherlands), 2003. 959

5 van der Linden, P. and Mitchell, J. F. B. (Eds.): ENSEMBLES: Climate Change and its Impacts: Summary of Research and Results from the ENSEMBLES Project, Met Office Hadley Centre, Exeter, UK, 2009. 955, 958

Nakicenovich, N. and Swart, R. (Eds.): Special Report on Emissions Scenarios - A Special Report of Working Group III of the IPCC, Cambridge University Press, Cambridge, UK, 2000. 958

Mapping of natural and technical disasters, Technical report, European Environment Agency, Copenhagen, 2011. 954

Piani, C., Haerter, C. J., and Coppola, E.: Statistical bias correction for daily precipitation in regional climate models over europe, Theor. Appl. Climatol., 99, 187-192, 2010a. 955, 956, 957

Piani, C., Weedon, G. P., Best, M., Gomes, S. M., Viterbo, P. Hagemann, S., and Haerter, J. O.: Statistical bias correction of global simulated daily precipitation and temperature for the application of hydrological models, J. Hydrol., 395, 199-215, 2010b. 955

Roeckner, E., Bäuml, G., Bonaventura, L., Brokopf, R., Esch, M., Giorgetta, M., Hagemann, S., Kirchner, I., Kornblueh, L., Manzini, E., Rhodin, A., Schlese, U., Schulzweida, U., and Tompkins, A.: The atmospheric general circulation model echam5, Technical Report, Max-Planck Institute for meteorology, 349, 2003. 958, 959

Semenov, M. A. and Doblas-Reyes, F. J.: Utility of dynamical seasonal forecasts ub predicting crop-yield. Climate Res., 34, 71-81, 2007. 955

Sennikovs, J. and Bethers, U.: Statistical dowscalling method of regional climate model results for hidrological modelling, in: 18th World IMACS/MODSIM Congress, 2377-2383, Carns Australia, July 2009. 956

Sharma, D., Das Gupta, A., and Babel, M. S.: Spatial disaggregation of bias-corrected GCM precipitation for improved hydrologic simulation: Ping River Basin, Thailand, Hydrol. Earth Syst. Sci., 11, 1373-1390, doi:10.5194/hess-11-1373-2007, 2007. 955

Solomon, S., Qin, D., Manning, M., Marquis, M., Averyt, K., Tignor, M. M. B., Miller, H. L., and Chen, Z. (Eds.): Climate Change 2007: The Physical Science Basis, Cambridge University Press, Cambridge, UK, 2007. 954
8, 953-986, 2012

\section{Correcting mean and extremes in monthly precipitation}

B. Kurnik et. al

\section{Title Page}

Abstract

Introduction

Conclusions

References

Tables

Figures

14

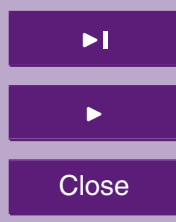

Back

Close

Full Screen / Esc

Printer-friendly Version

Interactive Discussion

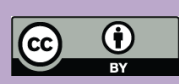


Somot, S.: First simulation with cnrm-rm4: Era40@50km validation over europe, in: ENSEMBLES RT3, UK Met Office, Exeter, UK, 2006. 959

Thom, H. C. S.: A note on the gamma distribution, Mon. Weather Rev., 86, 117-122, 1958. 957

Wang, G. L.: Agricultural drought in the future climate: results from 15 global climate models participating in the IPCC 4th assessment, Climate Dynam., 25, 739-753, 2005. 954

Wilks, D. S.: Maximum likelihood estimations for gamma distribution using data containing zeros, J. Climate, 3, 1495-1501, 1990. 957

\section{8, 953-986, 2012}

\section{Correcting mean and} extremes in monthly precipitation

B. Kurnik et. al

Title Page

Abstract

Conclusions

Tables

References

Figures

14

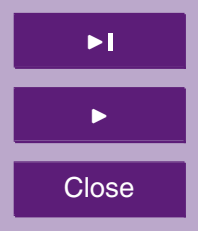

Back

Full Screen / Esc

Printer-friendly Version

Interactive Discussion 


\section{8, 953-986, 2012}

\section{Correcting mean and}

extremes in monthly precipitation

Table 1. Normalized deviation of individual ensemble members for winter and summer precipitation. Deviation of the signal from ensemble mean is expressed in units of the intra-ensemble standard deviation.

\begin{tabular}{ccrr}
\hline Model code & Model name & \multicolumn{2}{c}{$\begin{array}{c}\text { Precipitation anomaly (in SD) } \\
\text { DJF }\end{array}$} \\
\hline JJA \\
\hline (SM1) & SMHI-RCA3 (BCM) & 0.686 & 0.223 \\
(SM2) & SMHI-RCA3 (ECHAM5) & 0.355 & 0.510 \\
(MPI) & MPI-REMO (ECHAM5) & -1.009 & -0.284 \\
(KNM) & KNMI-RACMO (ECHAM5) & -0.620 & 0.223 \\
(ETH) & ETHZ-CLM (HadCM3Q0) & 1.020 & -0.400 \\
(DM1) & DMI-HIRLAM (ECHAM5) & 1.182 & 1.928 \\
(DM2) & DMI-HIRLAM (ARPEGE) & -1.535 & -1.092 \\
(CNR) & CNRM-ALADIN (ARPEGE) & -0.815 & 0.928 \\
\hline
\end{tabular}

Title Page

Abstract

Introduction

Conclusions

References

Tables

Figures

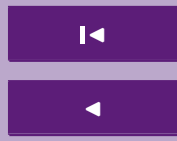

Back

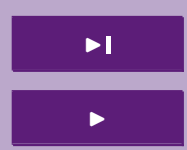

Close

Full Screen / Esc

Printer-friendly Version

Interactive Discussion 


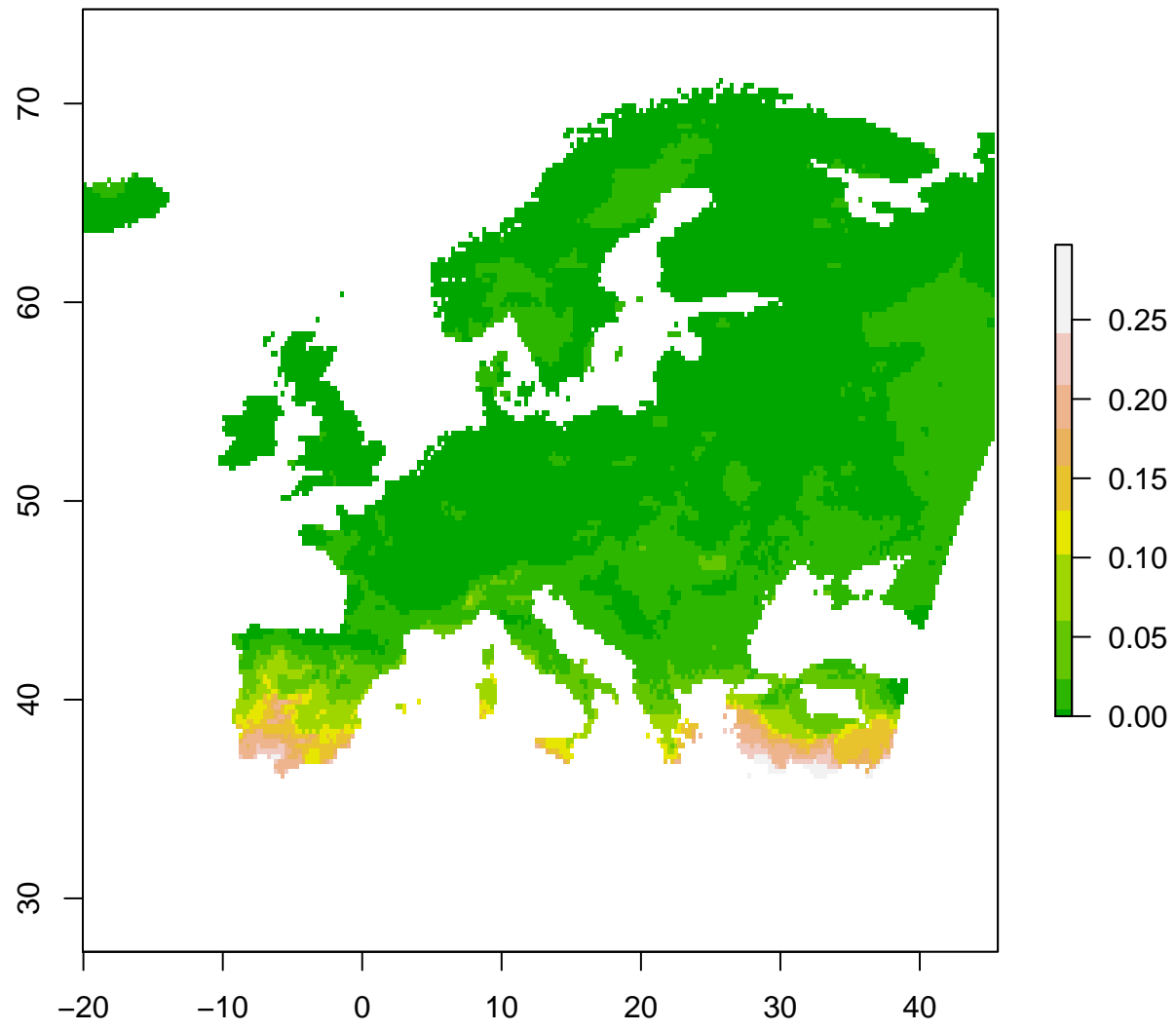

8, 953-986, 2012

Correcting mean and extremes in monthly precipitation

B. Kurnik et. al

Title Page

\begin{tabular}{|c|c|}
\hline Abstract & Introduction \\
\hline Conclusions & References \\
\hline Tables & Figures \\
\hline I4 & $\bullet \mathbf{I}$ \\
\hline 4 & $\triangleright$ \\
\hline Back & Close \\
\hline Full Screen / Esc
\end{tabular}

Printer-friendly Version

Fig. 1. Probability for observed dry month over Europe.

Interactive Discussion 


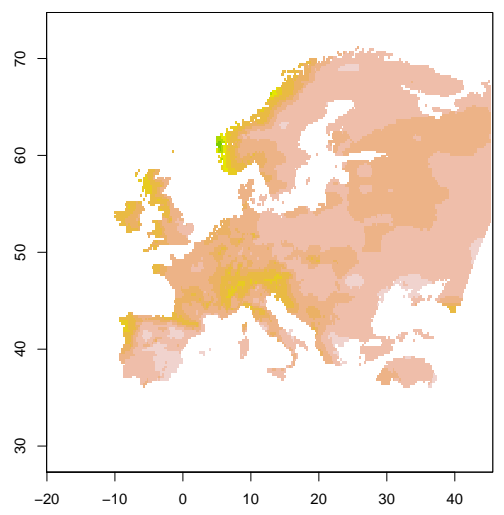

(a) Yearly

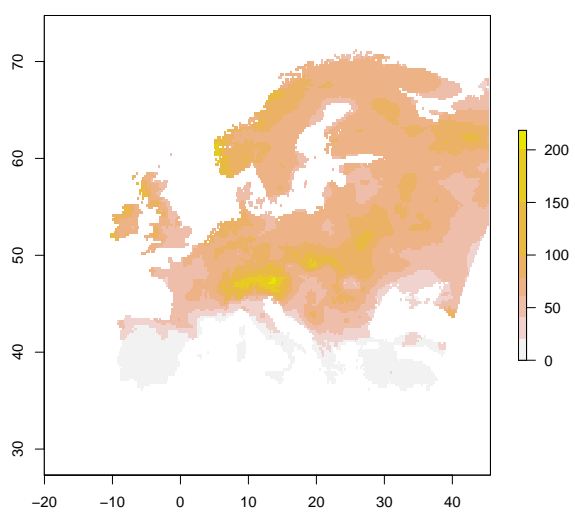

(b) July

Fig. 2. Mean yearly (a) and July (b) precipitation.

Correcting mean and extremes in monthly precipitation

B. Kurnik et. al Title Page

\begin{tabular}{c|c|}
\hline Abstract & Introduction \\
\hline Conclusions & References \\
\hline Tables & Figures \\
\hline I4 & $\bullet \mathbf{I}$ \\
\hline 4 & $\triangleright$ \\
\hline Back & Close \\
\hline Full Screen / Esc
\end{tabular}

Printer-friendly Version

Interactive Discussion

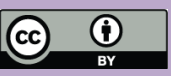




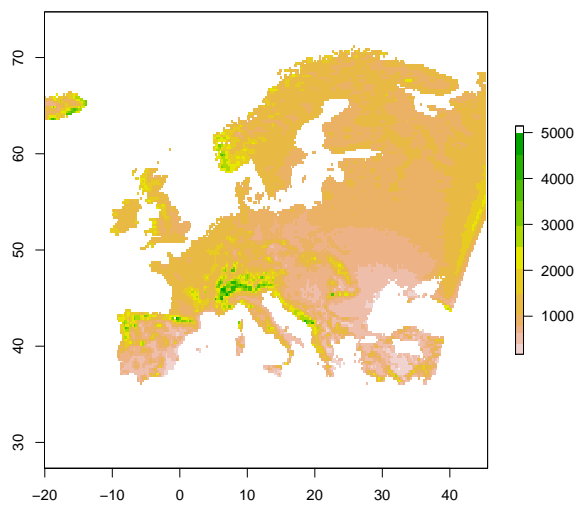

(a) Simulated

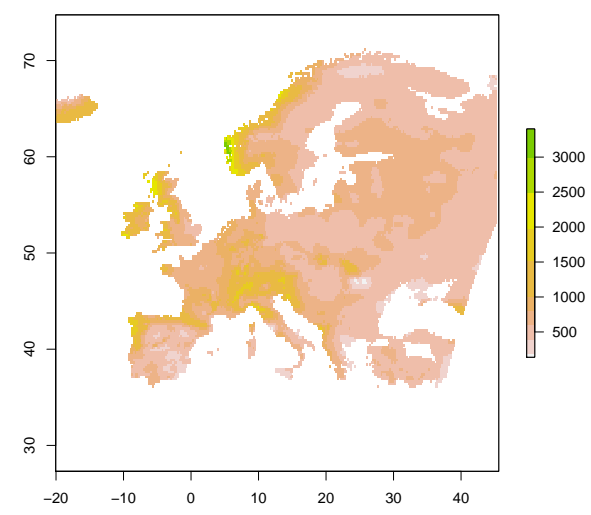

(b) Corrected

Fig. 3. Ensemble mean of simulated (a) and corrected (b) average yearly precipitation.

Correcting mean and extremes in monthly precipitation

B. Kurnik et. al

Title Page

\begin{tabular}{|c|c|}
\hline Abstract & Introduction \\
\hline Conclusions & References \\
\hline Tables & Figures \\
\hline I4 & $\bullet$ \\
\hline 4 & $\checkmark$ \\
\hline Back & Close \\
\hline Full Screen / Esc \\
\hline Printer-friendly Version \\
\hline Interactive Discussion
\end{tabular}

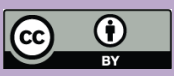




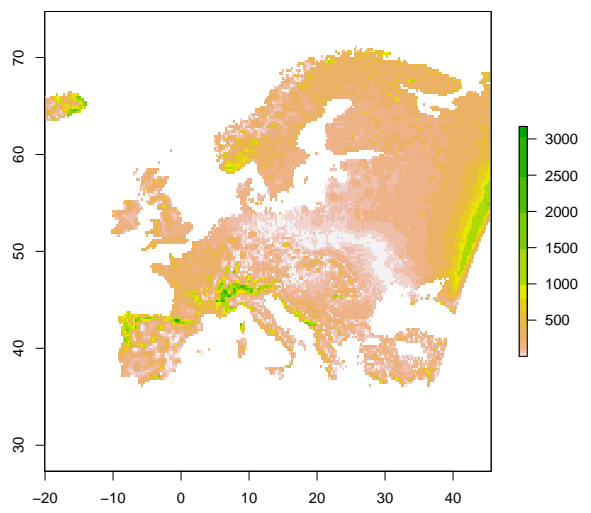

(a) Simulated

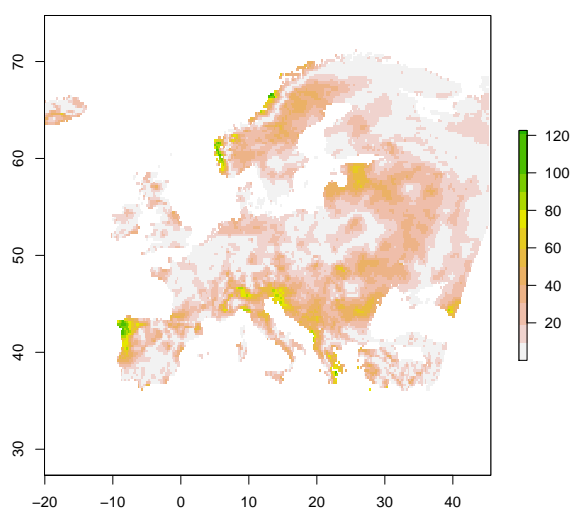

(b) Corrected

Fig. 4. Ensemble spread of the simulated (a) and corrected (b) average yearly precipitation.

Correcting mean and extremes in monthly precipitation

B. Kurnik et. al Title Page

\begin{tabular}{c|c|}
\hline Abstract & Introduction \\
\hline Conclusions & References \\
\hline Tables & Figures \\
\hline I4 & $\bullet \mathbf{I}$ \\
\hline 4 & $\triangleright$ \\
\hline Back & Close \\
\hline Full Screen / Esc
\end{tabular}

Printer-friendly Version

Interactive Discussion

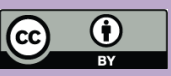




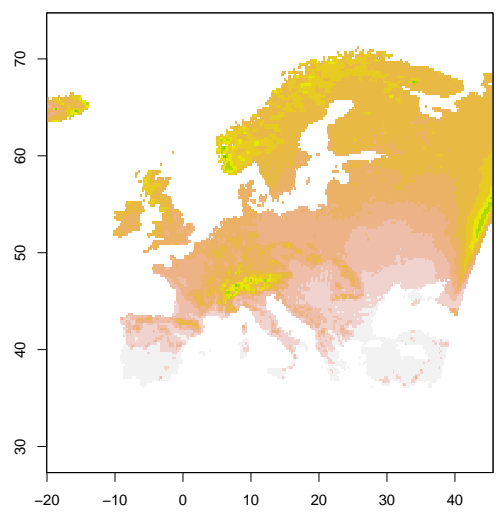

(a) Simulated

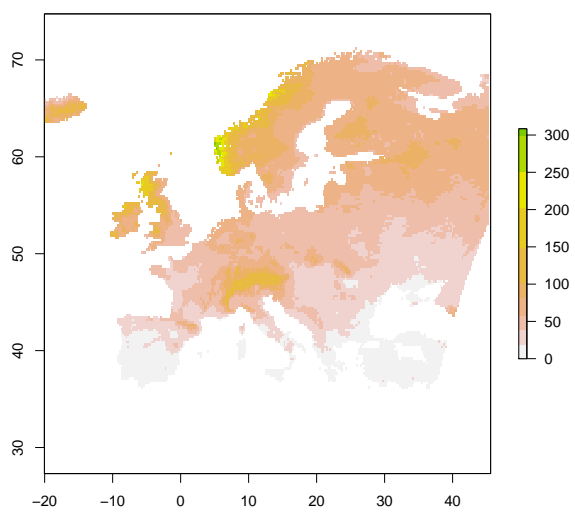

(b) Corrected

Fig. 5. Ensemble mean of the simulated (a) and corrected (b) average July precipitation.

Correcting mean and extremes in monthly precipitation

B. Kurnik et. al Title Page

\begin{tabular}{c|c|}
\hline Abstract & Introduction \\
\hline Conclusions & References \\
\hline Tables & Figures \\
\hline I & $\bullet$ \\
\hline 4 & $\triangleright$ \\
\hline Back & Close \\
\hline Full Screen / Esc
\end{tabular}

Printer-friendly Version

Interactive Discussion

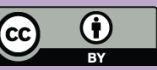




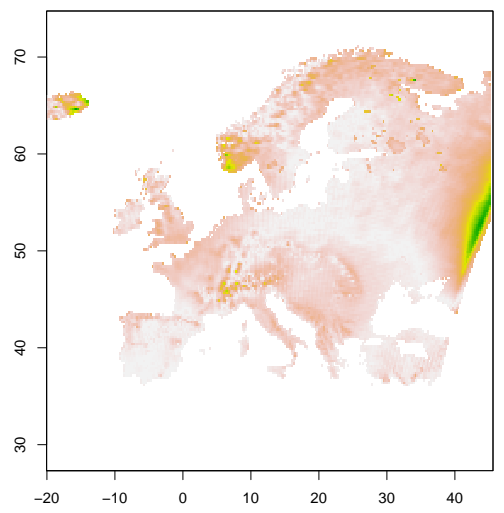

(a) Simulated

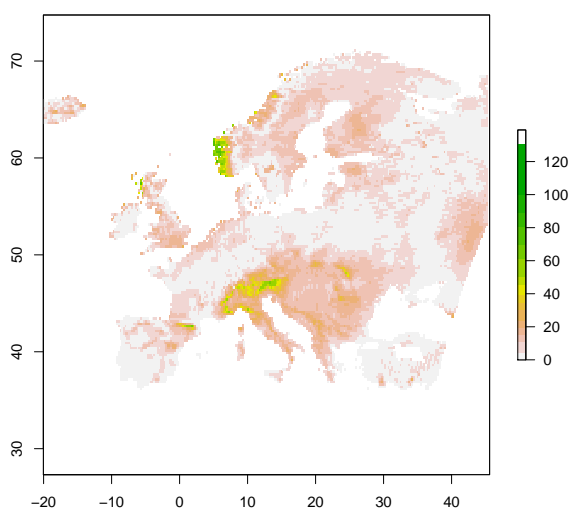

(b) Corrected

Fig. 6. Ensemble spread of the simulated (a) and corrected (b) average July precipitation.

Correcting mean and extremes in monthly precipitation

B. Kurnik et. al Title Page

\begin{tabular}{c|c|}
\hline Abstract & Introduction \\
\hline Conclusions & References \\
\hline Tables & Figures \\
\hline I4 & $\bullet \mathbf{I}$ \\
\hline 4 & $\triangleright$ \\
\hline Back & Close \\
\hline Full Screen / Esc
\end{tabular}

Printer-friendly Version

Interactive Discussion

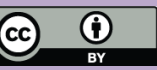




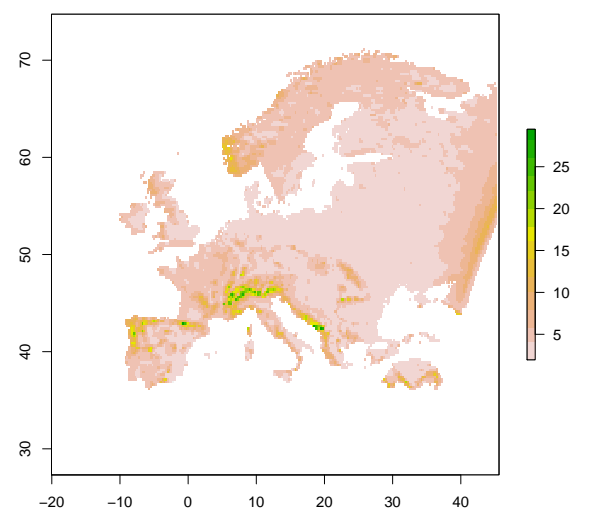

(a) Simulated

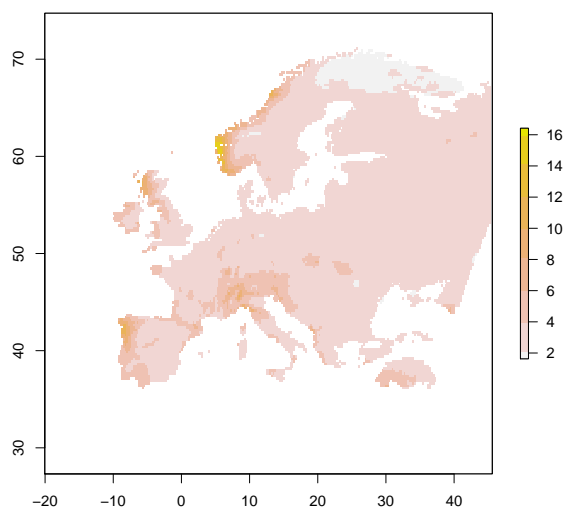

(b) Corrected

Fig. 7. RMSE of the simulated (a) and corrected (b) precipitation.

Correcting mean and extremes in monthly precipitation

B. Kurnik et. al

Title Page

\begin{tabular}{|c|c|}
\hline Abstract & Introduction \\
\hline Conclusions & References \\
\hline Tables & Figures \\
\hline I4 & \multicolumn{1}{|c|}{} \\
\hline 4 & \\
\hline Back & Close \\
\hline Full Screen / Esc \\
\hline Printer-friendly Version \\
\hline Interactive Discussion
\end{tabular}

@ 0 


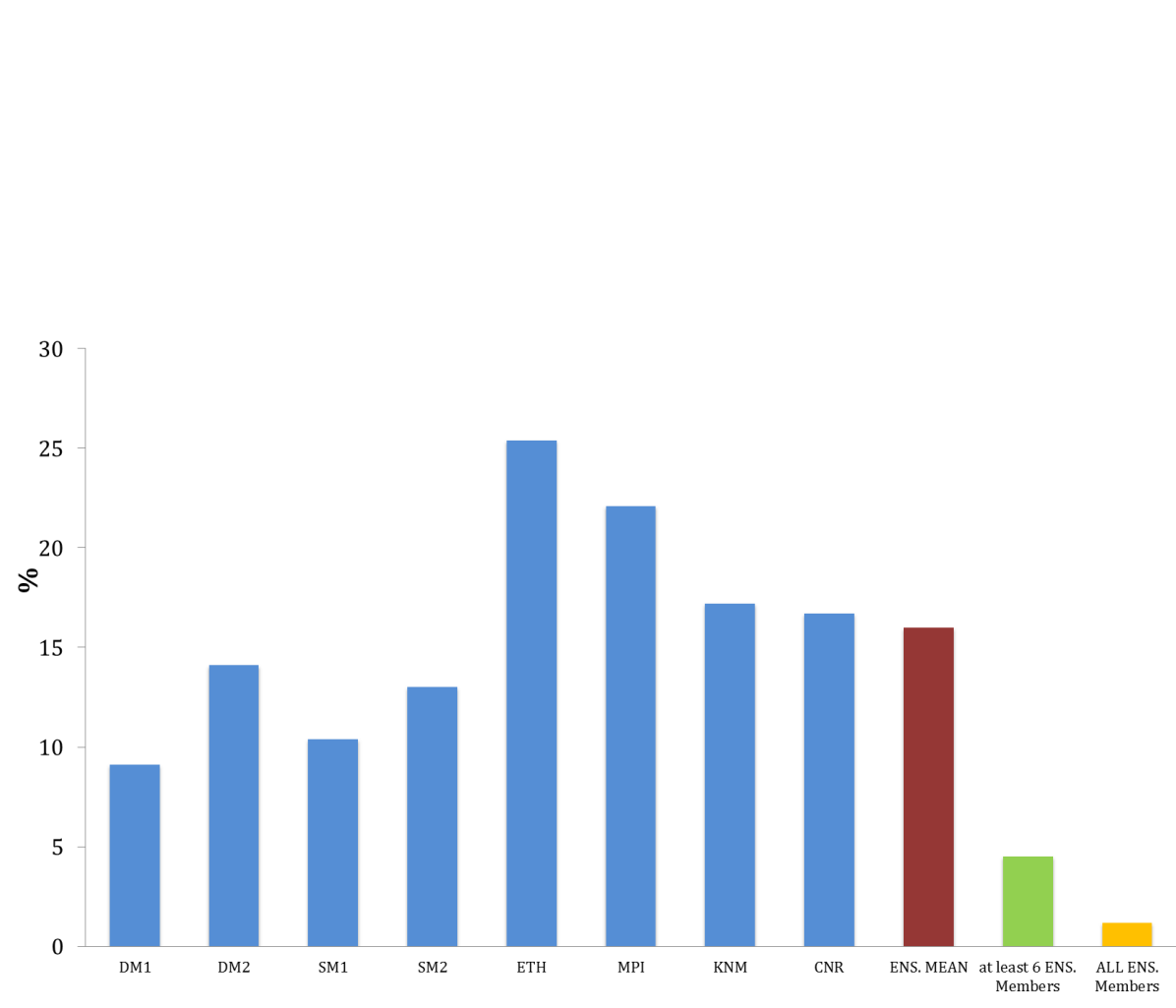

Fig. 8. Percentage of the area where correction failed.

8, 953-986, 2012

Correcting mean and extremes in monthly precipitation

B. Kurnik et. al

Title Page

Abstract Introduction

Conclusions References

Tables

Figures

14

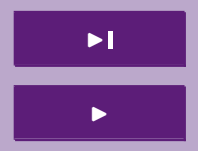

Back

Close

Full Screen / Esc

Printer-friendly Version

Interactive Discussion 


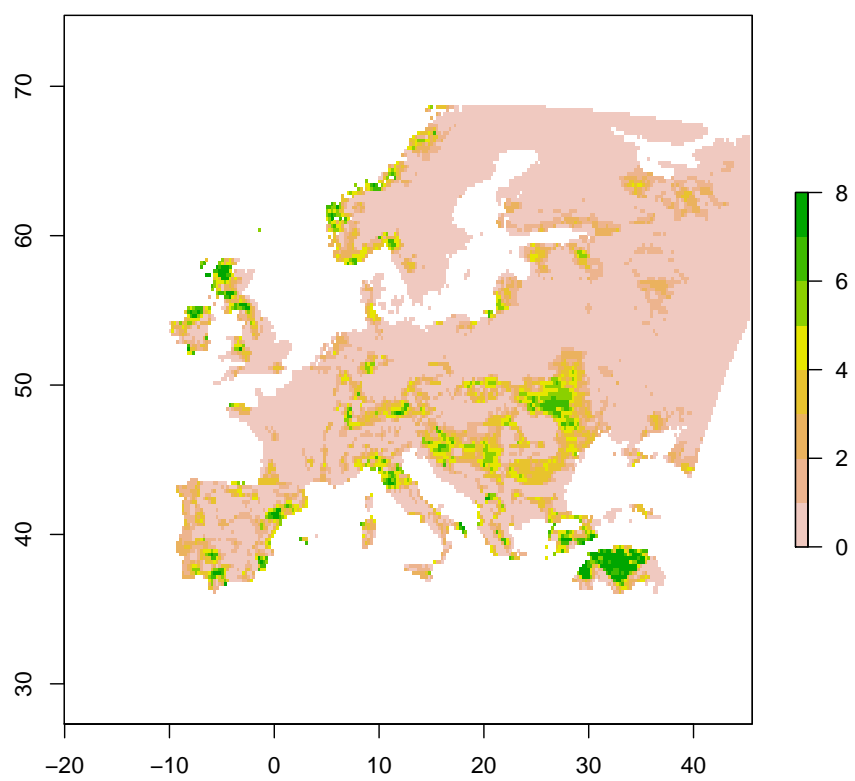

Fig. 9. Number of models for which correction failed over Europe. 


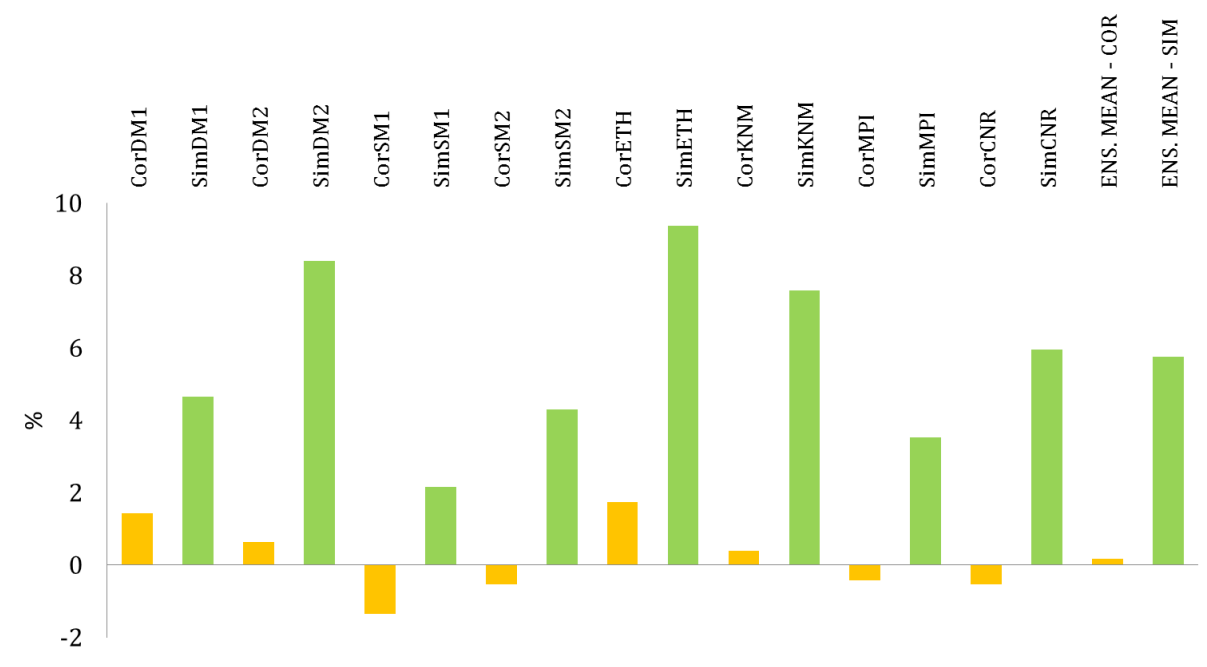

Fig. 10. Average areal differences in percentages between modeled (corrected and simulated) and observed dry months.
8, 953-986, 2012

Correcting mean and extremes in monthly precipitation

B. Kurnik et. al

Title Page

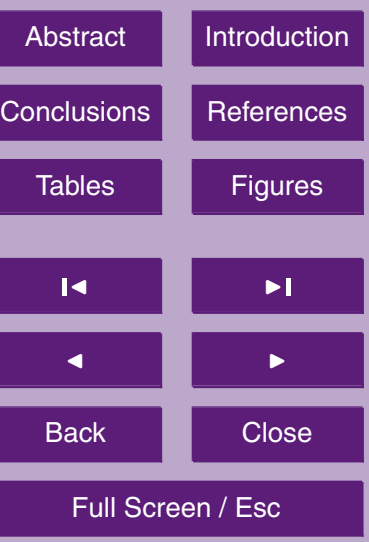

Printer-friendly Version

Interactive Discussion

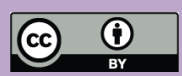




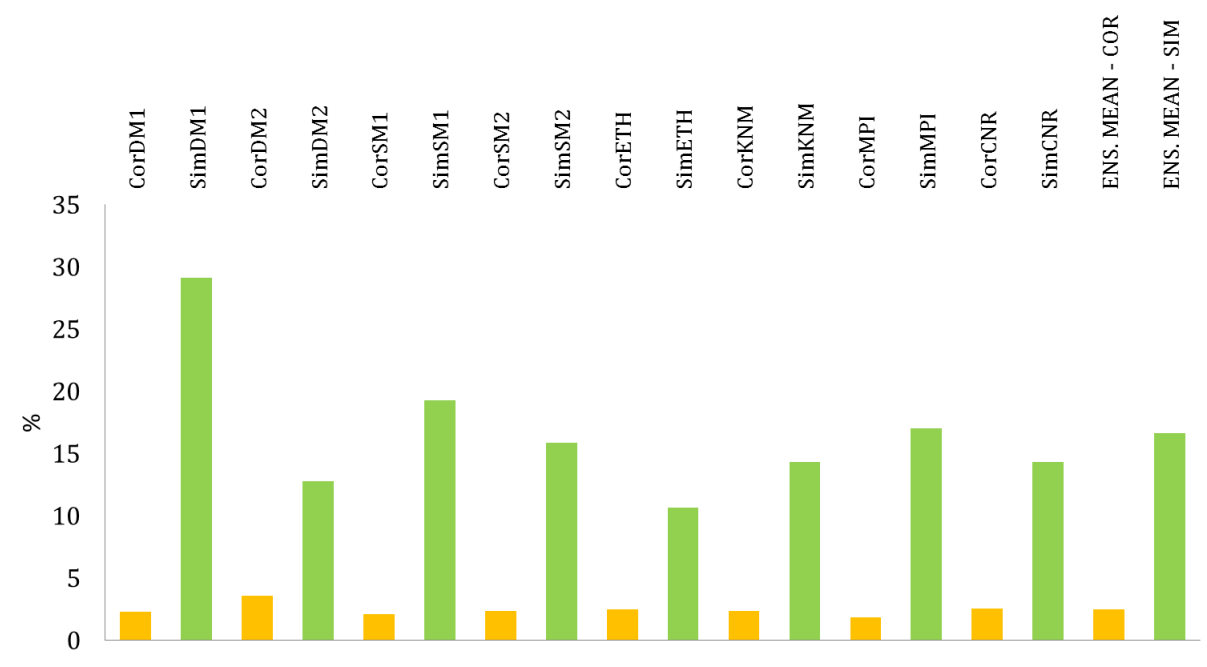

Fig. 11. Average areal differences in percentages between modeled (corrected and simulated) and observed monthly precipitation above $200 \mathrm{~mm}$.
8, 953-986, 2012

Correcting mean and extremes in monthly precipitation

B. Kurnik et. al

Title Page

Abstract

Introduction

Conclusions

References

Tables

Figures

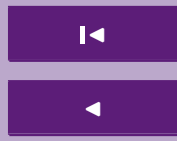

Back

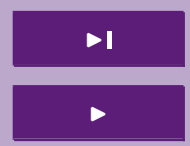

Close

Full Screen / Esc

Printer-friendly Version

Interactive Discussion

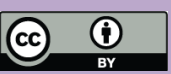




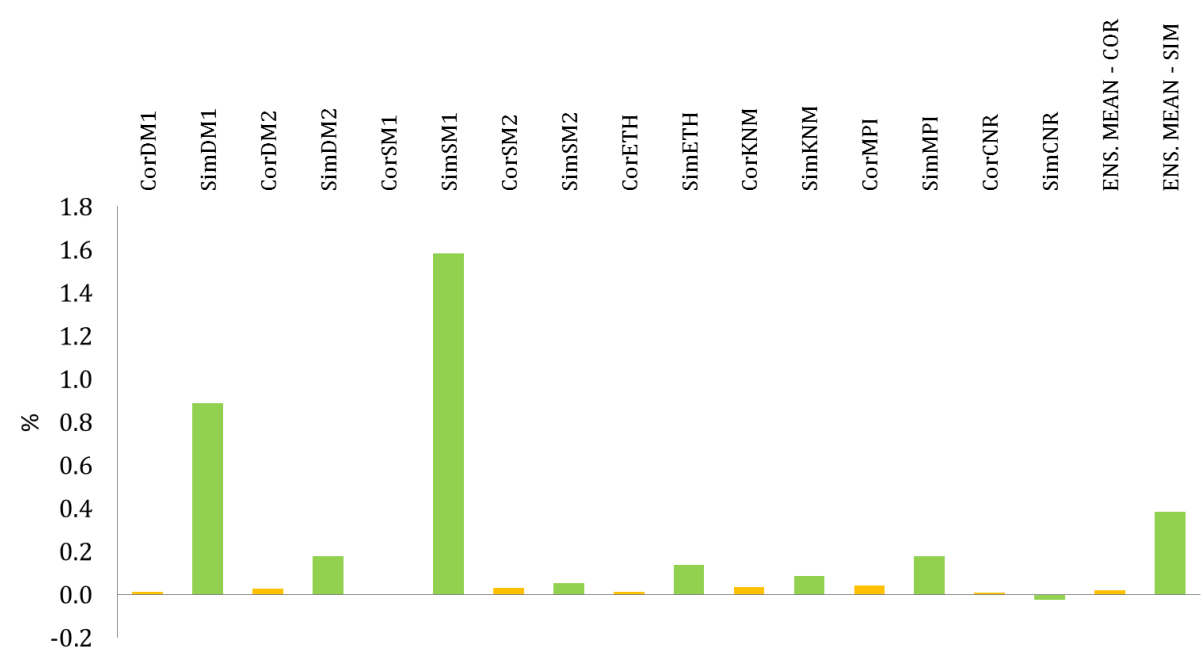

Fig. 12. Average areal differences in percentages between modeled (corrected and simulated) and observed monthly precipitation above $400 \mathrm{~mm}$.
8, 953-986, 2012

Correcting mean and extremes in monthly precipitation

B. Kurnik et. al

Title Page

Abstract

Introduction

Conclusions

References

Tables

Figures

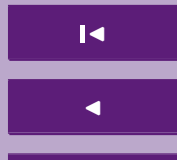

Back

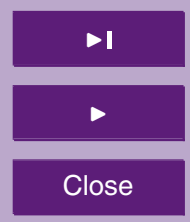

Full Screen / Esc

Printer-friendly Version

Interactive Discussion

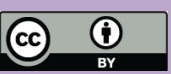




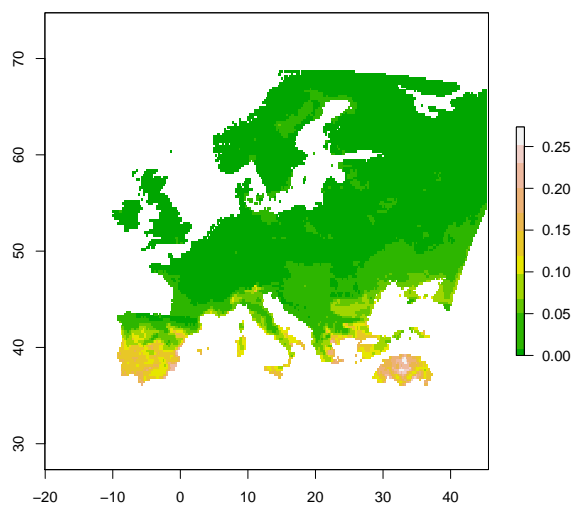

(a) Simulated

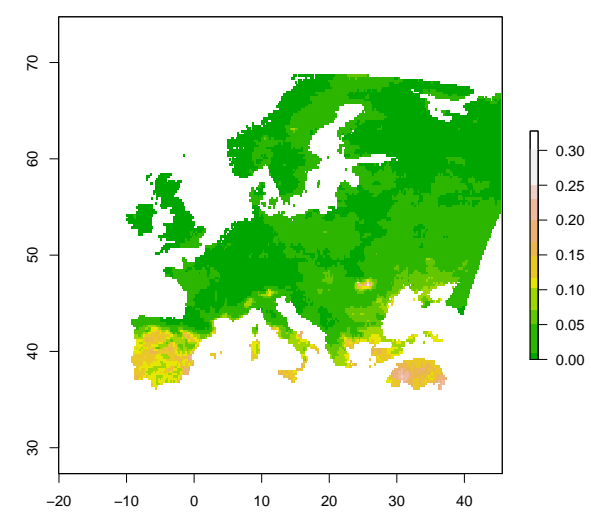

(b) Corrected

Fig. 13. Brier Score for simulated (a) and corrected (b) zero precipitation.

Correcting mean and extremes in monthly precipitation

B. Kurnik et. al

Title Page

\begin{tabular}{|c|c|}
\hline Abstract & Introduction \\
\hline Conclusions & References \\
\hline Tables & Figures \\
\hline I4 & $\bullet$ \\
\hline 4 & $\triangleright$ \\
\hline Back & Close \\
\hline Full Screen / Esc
\end{tabular}

Printer-friendly Version

Interactive Discussion

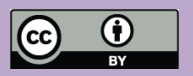




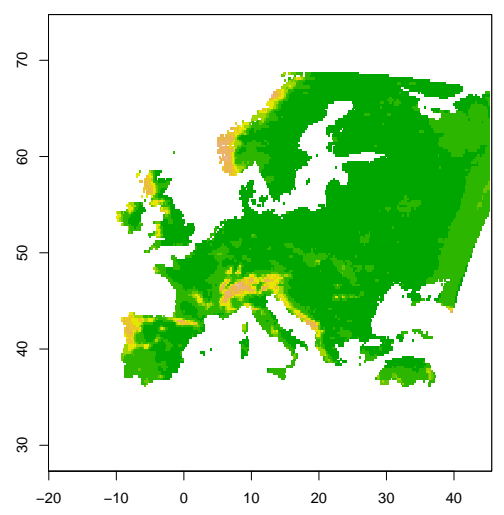

(a) Simulated

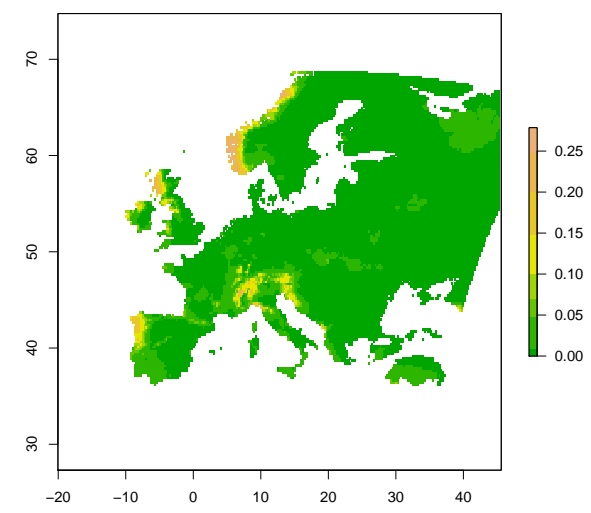

(b) Corrected

Fig. 14. Same as Fig. 13b, but for heavy precipitation.

Correcting mean and extremes in monthly precipitation

B. Kurnik et. al

Title Page

Abstract

Conclusions

Tables

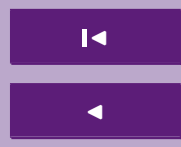

Back Introduction References

\section{Figures}

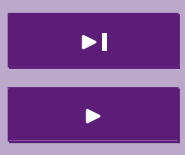

Close

Full Screen / Esc

Printer-friendly Version

Interactive Discussion

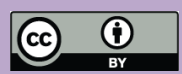




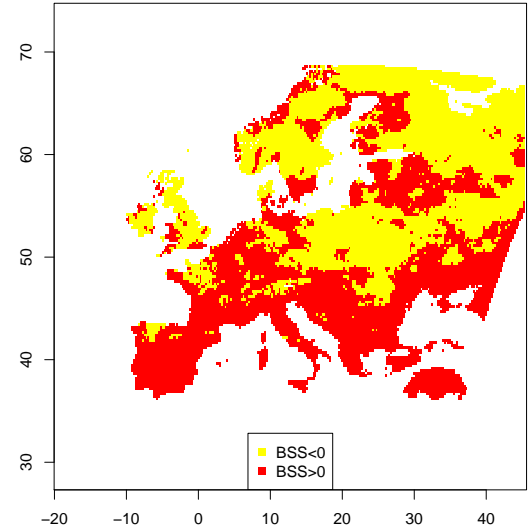

(a)

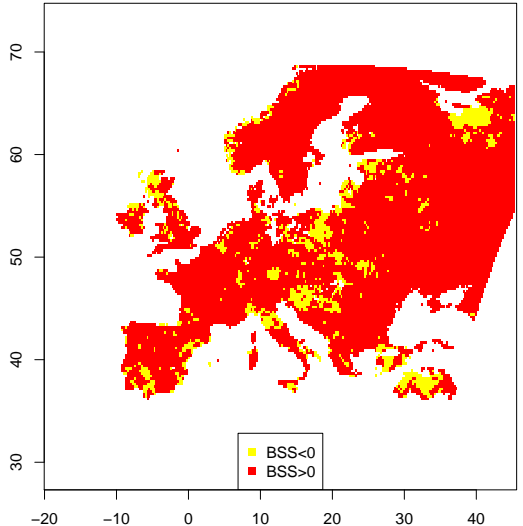

(b)

Fig. 15. Brier Skill Score for dry months (a) and heavy precipitation (b).

8, 953-986, 2012

Correcting mean and extremes in monthly precipitation

B. Kurnik et. al

Title Page

\begin{tabular}{c|c|}
\hline Abstract & Introduction \\
\hline Conclusions & References \\
\hline Tables & Figures \\
\hline I4 & $\bullet \mathbf{I}$ \\
\hline 4 & $\triangleright$ \\
\hline Back & Close \\
\hline Full Screen / Esc
\end{tabular}

Printer-friendly Version

Interactive Discussion

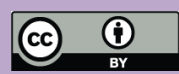

